\title{
THE COMMISSION OF THE EUROPEAN COMMUNITIES
}

is pleased to announce the publication of

\section{REGISTER OF CURRENT COMMUNITY LEGAL INSTRUMENTS}

The first edition of the register of current Community legal instruments gives references for all binding Community legislation in force as at 1 July 1979:

- legislation derived from the Treaties establishing the three European Communities;

- supplementary legislation,

- agreements between the Communities and non-member countries.

References are classified by subject. For ease of research the analytical section has two indexes - one of them lists key words in alphabetical order and the other is a list of numbers. References to acts that cover several different subjects appear under each of the relevant subject headings. Wherever an act has been amended there is a full reference to the amending act. Most of the citations are to the Official Journal of the European Communities.

The work is in two volumes. The first contains the analytical section, the alphabetical index and guidance for the reader. The second is the chronological index by number of all the acts given in the analytical section. The catalogue has been divided into two volumes in order to make it easier to use.

The register is published in all the Community languages and will be recompiled and updated each year.

ISBN 92-825-1440-4 (Volume I)

ISBN 92-825-1798-5 (Volumes I and II)

Catalogue number: FX-80-79-001-EN-C

Price for Volumes $I$ and 11 inclusive

Bfrs 1500 Dkr 275 DM 93 FF 218 \& IRL 24.80

Lit 42900 Fl $103,50 £ 24.80$ \$US 52

Payment is due on receipt of invoiche.

OFFICE FOR OFFICIAL PUBLICATIONS OF THE EUROPEAN COMMUNITIES

Boite postale 1003 - Luxembourg 


\section{HAGUE-ZAGREB ESSAYS 3}

\section{Carriage of Goods by Sea, Maritime Collisions, Maritime Oil Pollution, Commercial Arbitration}

Hague-Zagreb Colloquium on the Law of International Trade

Session 1978, Opatija

edited by C.C.A. Voskuil and J.A. Wade

1980, 342 pp., paper Dfl. 65.00/\$32.50 ISBN 9028607498

In 1971, the Institute for International Law and International Relations in Zagreb organized a round table conference in Yugoslavia on international law with staff members of the T.M.C. Asser Institute for International Law at The Hague, the Netherlands. The experience derived from the successful meeting inspired both Institutes to engage upon the joint venture of a biennial colloquium on the law of international trade as a means of facilitating exchanges of legal information and discussions between legal scholars and institutions in Eastern and Western Europe. This was made feasible by a subvention from the Yugoslav and Dutch Government under the Cultural Treaty concluded between both states in 1971. The first session of the colloquium was held in Yugoslavia, in May 1974, the second in the Netherlands in May 1976. The papers presented to the Colloquium, together with a summary of the discussions, have been published; those for the (first) $Z$ agreb Session as Essays on the Law of International Trade, edited and published by the T.M.C. Asser Institute for International Law, The Hague 1976 (out of print), those for the (second) Hague Session as Hague-Zagreb Essays 2: Product Liability, Road Transport, Foreign Law, edited by the T.M.C. Asser Institute, The Hague and published by Sijthoff and Noordhoff 1978,269 pp.; paper Dfl. $56.00 / \$ 26.00$ ISBN 9028604782 .

\section{Contents:}

Carriage of Goods by Sea

Contractual liability for carriage of goods by sea (The Hague Rules and the Hamburg Rules), by $R$. Cleton and $E$. Pallua.

\section{Maritime Collisions}

Limitation of non-contractual liability resulting from collisions at sea (excluding pollution aspects), by $L$. Erades and $V$. Filipović.

\section{Maritime Oil Pollution}

International pollution of the sea, by $M$. Sumampouw and B. Bohte \& B. Vukas.

Commercin Arbitration

Bona fides in international commercial arbitration, by $A$. Goldstajn and J.D.M. Lew.

\section{Student reports on a Maritime Collision and Oil Pollution Case}

Contributors E. Bruner \& M. Miloradov, M.J. Dalman \& H.L. van Moppes, and E.J. de Muïnck Hughes.

Please order through your bookseller or Sijthoff \& Noordhoff International Publishers, Order Department P.O. Box 42400 MA Alphen aan den Rijn, The Netherlands or 1600, Research Boulevard, Rockville, Md. 20850, USA.

Prices are subject to change without notice. 